\title{
DINAMIKA JUMLAH BAKTERI Bacillus subtillis DALAM PENURUNAN KADAR BAHAN ORGANIK TOM LIMBAH BUDIDAYA IKAN LELE SANGKURIANG (Clarias gariepinus)
}

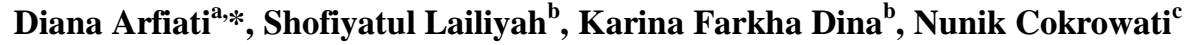 \\ ${ }^{a}$ Dosen Manjamenen Sumberdaya Perairan, Fakultas Perikanan dan Ilmu Kelautan, \\ Universitas Brawijaya, Malang, Indonesia \\ ${ }^{\mathrm{b}}$ Mahasiswa Manjamenen Sumberdaya Perairan, Fakultas Perikanan dan Ilmu Kelautan, \\ Universitas Brawijaya, Malang, Indonesia \\ ${ }^{c}$ Dosen Budidaya Perairan, Universitas Mataram, Mataram, Indonesia \\ *Koresponden penulis : d-arfiati@ub.ac.id
}

\begin{abstract}
Abstrak
Air sisa budidaya ikan lele berupa bahan organik apabila dibuang ke perairan secara terus menerus dan berlebihan mengakibatkan pengkayaan nutrisi di perairan sehingga terjadi perubahan lingkungan. Upaya pengelolaan yang dapat dilakukan untuk menurunkan kadar bahan organik adalah menggunakan metode bioremediasi dengan penambahan bakteri Bacillus subitilis. Tujuan dari penelitian ini adalah untuk mengetahui pengaruh dinamika jumlah bakteri Bacillus subtilis dalam menurunkan kadar bahan organik pada limbah budidaya ikan lele Sangkuriang (Clarias gariepinus). Metode yang digunakan adalah metode eksperimen dengan rancangan acak lengkap (RAL) faktorial dengan 2 perlakuan. Adapun 2 perlakuan tersebut yaitu perlakuan waktu inkubasi $(24,48,72,96$ dan 120 jam) dan perlakuan kepadatan bakteri yaitu $10^{7} \mathrm{CFU} / \mathrm{mL}, 10^{6} \mathrm{CFU} / \mathrm{mL}$ dan $10^{5} \mathrm{CFU} / \mathrm{mL}$. Parameter diukur adalah kepadatan bakteri, bahan organic total, $\mathrm{pH}$, suhu dan oksigen terlarut. Hasil pengukuran kepadatan bakteri Bacillus subtillis mengalami peningkatan jumlah bakteri pada semua perlakuan kepadatan setiap 24 jam. Hasil kepadatan bakteri berkisar antara 2,44 x $10^{5} \mathrm{CFU} / \mathrm{ml}$ sampai 5,3 x $10^{7} \mathrm{CFU} / \mathrm{ml}$. Selama masih ada bahan organik maka bakteri akan tetap berkembang, bakteri akan menurun seiring nutrientnya habis, jika menurunkan bahan organik dalam waktu 5 hari, tetapi untuk bakteri membutuhkan waktu lebih dari 5 hari bahan organik tidak terdegradasi $100 \%$.
\end{abstract}

Kata kunci : Ikan Lele, Degradasi, Feses, Mikroorganisme, Pakan

\begin{abstract}
Water left over from catfish farming in the form of organic material when discharged into water continuously and excessively results in enrichment of nutrients in the waters resulting in environmental changes. Management efforts that can be done to reduce levels of organic matter are using the bioremediation method with the addition of Bacillus subitilis. The purpose of this study was to determine the effect of the dynamics of the number of Bacillus subtilis bacteria in reducing levels of organic matter in Sangkuriang catfish farming waste (Clarias gariepinus). The method used is an experimental method with a completely randomized design (CRD) factorial with 2 treatments. The 2 treatments are incubation time treatment $(24,48,72,96$ and 120 hours) and bacterial density treatment that is $10^{7} \mathrm{CFU} / \mathrm{mL}, 10^{6} \mathrm{CFU} / \mathrm{mL}$ and $10^{5} \mathrm{CFU} / \mathrm{mL}$. The parameters measured were bacterial density, total organic matter, $\mathrm{pH}$, temperature and dissolved oxygen. The results of the measurement of bacterial density Bacillus subtillis have increased the number of bacteria in all density treatments every 24 hours. Bacterial density results ranged from 2.44 x $10^{5} \mathrm{CFU} / \mathrm{ml}$ to $5.3 \times 10^{7} \mathrm{CFU} / \mathrm{ml}$. As long as there is organic matter, the bacteria will continue to grow, the bacteria will decrease as the nutrients run out, if the organic matter is reduced within 5 days, but for bacteria it takes more than 5 days the organic material is not degraded $100 \%$.
\end{abstract}

Keywords : Catfish, Degradation, Feces, Microorganism, Feed

\section{PENDAHULUAN}

Budidaya pembesaran ikan, akhir-akhir ini semakin mendapat perhatian dan mulai berkembang di Indonesia, terutama karena ikan mempunyai kandungan gizi yang cukup tinggi dan bernilai ekonomis namun disisi lain limbah hasil budidaya yang dihasilkan dapat menurunkan kualitas perairan. 
Pembudidayaan ikan adalah kegiatan untuk memelihara, membesarkan dan membiakkan ikan dan memanen hasilnya dalam lingkungan yang terkontrol [1].

Air sisa budidaya ikan Lele berupa bahan organik apabila dibuang ke perairan secara terus menerus dan berlebihan mengakibatkan pengkayaan nutrisi di perairan sehingga terjadi perubahan lingkungan [2]. Peningkatan bahan organik dari inlet ke outlet mencapai $318,88 \%$ di mana rata-rata pada inlet mulanya sebesar $28,01 \mathrm{mg} / \mathrm{L}$ menjadi 89,33 $\mathrm{mg} / \mathrm{L}$. Air sisa budidaya yang dibuang langsung ke perairan umum akan mengakibatkan menurunnya kualitas air dan berdampak pada organisme perairan di dalamnya [3].

Upaya pengelolaan yang dapat dilakukan untuk menurunkan kadar bahan organik adalah dengan menggunakan metode bioremediasi dalam penelitian ini yaitu penambahan bakteri Bacillus subtillis. Bakteri berperan sebagai agen pengendali biologi yaitu dapat memperbaiki kualitas air melalui pendegradasian bahan organik. Bakteri Bacillus subitilis merupakan bakteri gram positif yang dapat membantu proses penguraian bahan organik [4].

Tujuan dari penelitian ini adalah untuk mengetahui pengaruh dinamika jumlah bakteri Bacillus subtilis dalam menurunkan kadar bahan organik pada limbah budidaya ikan lele sangkuriang (Clarias gariepinus).

\section{METODE}

Penelitian dilakukan di laboratorium Hidrobiologi Divisi Sumberdaya Ikan, Fakultas Perikanan dan Ilmu Kelautan Universitas Brawiajaya pada bulan Januari 2019. Sampel air limbah budidaya ikan Lele Sangkuriang diambil dari kolam budidaya ikan Lele sangkuriang pada akhir budidaya selama tiga bulan di Intalasi Perikanan Budidaya Kepanjen. Sampel air diambil sebanyak 46 liter yang dimasukkan ke dalam derijen volume 25 liter sebanyak 2 buah. Selanjutnya sampel air akan dimasukkan ke dalam setiap bak percobaan sebanyak 4 liter.

Sampel air selanjutnya ditambahkan dosis bakteri Bacillus subtillis dengan tiga macam dosis yaitu $10^{7} \mathrm{CFU} / \mathrm{mL}, 10^{6} \mathrm{CFU} / \mathrm{mL}$ dan $10^{5} \mathrm{CFU} / \mathrm{mL}$ dengan waktu inkubasi 24 ,
48, 72, 96 dan 120 jam. Pengkuran kepadatan bakteri Bacillus subtillis dan parameter kualitas air $(\mathrm{pH}$, suhu, oksigen terlarut, dan bahan organik total ) dilakukan setiap 24 jam sekali.

Metode yang digunakan dalam penelitian metode eksperimen dengan rancangan acak lengkap (RAL) faktorial dengan dengan Analisa menggunakan Analisa Varian (ANOVA) Faktorial menggunakan software SPSS (Statistical Package for Sosial Science) Statistic 23.

\section{HASIL DAN PEMBAHASAN}

\section{Kurva Pertumbuhan Bakteri}

Kurva pertumbuhan bakteri bertujuan untuk mengetahui waktu bakteri memasuki fase logaritmik dan fase stasioner. Pengamatan fase pertumbuhan bakteri dilakukan setiap dua jam sekali dengan spektrofotometer dengan melihat nilai Optical Dencity. Panjang gelombang pada spektrometer menggunakan panjang gelombang $600 \mathrm{~nm}$. Kurva pertumbuhan bakteri Bacillus subtillis dapat dilihat pada Gambar 1.

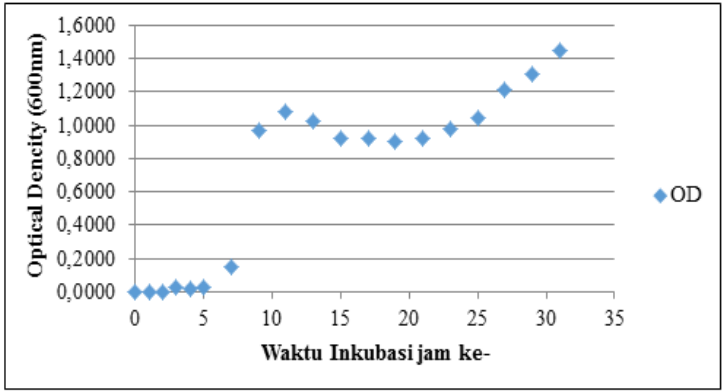

Gambar 1. Kurva Pertumbuhan Bakteri

Bakteri memasuki fase lag pada jam ke-0 sampai jam ke-4 selanjutnya bakteri akan memasuki fase eksponensial dimana bakteri mengalami pertumbuhan yang cepat pada jam ke-5sampai jam ke-9. Bakteri memperbanyak diri dengan cara membelah menjadi dua dan setiap generasi akan membelah dua kali lipat. Bakteri akan memasuki fase stasioner pada jam ke ke-9 sampai jam ke-24 Fase stasioner merupakan fase dimana bakteri mengalami pertumbuhan dan kematian dalam jumlah yang sama [5]. 


\section{Dinamika Pertumbuhan Bakteri}

Hasil pengukuran Total plate count bakteri Bacillus subtillis mengalami peningkatan jumlah bakteri pada semua perlakuan kepadatan setiap 24 jam. Hasil kepadatan bakteri berkisar antara 2,44 x $10^{5}$ $\mathrm{CFU} / \mathrm{ml}$ sampai 5,3 x $10^{7} \mathrm{CFU} / \mathrm{ml}$. Kepadatan bakteri $10^{5} \mathrm{CFU} / \mathrm{ml}$ pada jam ke 24 jumlah bakteri sebanyak 2,44 x $10^{5} \quad \mathrm{CFU} / \mathrm{ml}$ mengalami peningkatan pada jam ke 120 sebanyak 5,69 × $10^{5} \mathrm{CFU} / \mathrm{ml}$. Kepadatan bakteri $10^{6} \mathrm{CFU} / \mathrm{ml}$ pada jam ke 24 jumlah bakteri sebanyak 2,21 x $10^{6} \quad \mathrm{CFU} / \mathrm{ml}$ mengalami peningkatan pada jam ke 120 sebanyak 5,51 × $10^{6} \mathrm{CFU} / \mathrm{ml}$. Kepadatan bakteri $10^{7} \mathrm{CFU} / \mathrm{ml}$ pada jam ke 24 jumlah bakteri sebanyak $1,66 \quad$ x $10^{7} \quad \mathrm{CFU} / \mathrm{ml}$ mengalami peningkatan pada jam ke 120 sebanyak 5,3 x $10^{7} \quad \mathrm{CFU} / \mathrm{ml}$. Dinamika pertumbuhan bakteri dapat dilihat pada Gambar 2.

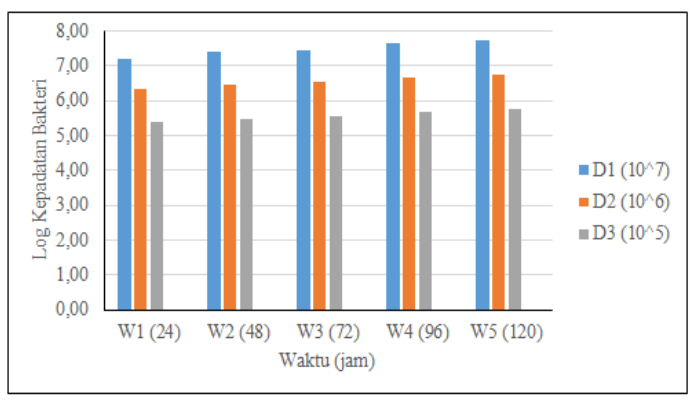

Gambar 2. Dinamika Pertumbuhan Bakteri

Jumlah kepadatan bakteri mengalami peningkatan pada setiap perlakuan karena bakteri mengalami pertumbuhan yang disebabkan oleh proses metabolisme. Bakteri memanfaatkan senyawa organik sebagai sumber karbon pertumbuhannya [6]. Peningkatan jumlah bakteri dipengaruhi oleh bahan organik sebagai nutrisi untuk pertumbuhan [7]. Pertumbuhan bakteri dipengaruhi oleh beberapa parameter seperti suhu, $\mathrm{pH}$ dan oksigen terlarut. Bakteri akan mengalami kematian apabila nutrisi dalam media tumbuh telah habis [8].

\section{Bahan Organik Total}

Hasil dari pengukuran bahan organik berkisar antara 13,03 - 79,73 mg/L. Bahan organik mengalami penurunan seiring dengan meningkatnya kepadatan bakteri (Gambar 3). Presentase penurunan bahan organik tertinggi sebesar 83,8\% (kadar awal 80,26 $\mathrm{mg} / \mathrm{L}$ menjadi $13,03 \mathrm{mg} / \mathrm{L}$ ) pada perlakuan dengan dosis penambahan bakteri Bacillus subtillis $10^{6} \mathrm{CFU} / \mathrm{ml}$. Bahan organik dan unsur hara diperlukan oleh mikroorganisme untuk proses metabolisme pertumbuhan. Adanya limbah organik akan dimanfaatkan oleh mikroorganisme untuk memproduksi sel-sel baru dan energi sehingga kepadatan bakateri meningkat [9].

Berdasarkan hasil Analisa Varian (ANOVA) Faktorial menunjukan nilai signifikan lebih kecil dari $\alpha(0,05)$ yang berarti bakteri Bacillus subtillis berpengaruh terhadap penurun kadar bahan organic total pada limbah budidaya ikan Lele Sangkuriang (Clarias gariepinus).

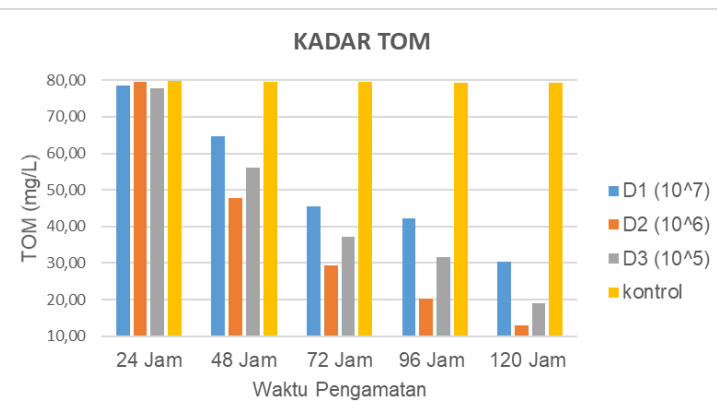

Gambar 3. Kadar Bahan Organik Total

\section{Parameter Kualitas Air}

Hasil pengukuran kualitias air diperoleh berkisar $25-37^{\circ} \mathrm{C}$. Bakteri Bacillus subtilis merupakan bakteri tipe mesofilik, dimana bakteri tipe ini dapat tumbuh diberbagai perairan [10]. Suhu optimum untuk bakteri yang masuk dalam tipe bakteri mesofilik berkisar antar $25-40^{\circ} \mathrm{C}$ [11].

Hasil pengukuran pH berkisar antara 6-7. sehingga nilai $\mathrm{pH}$ dalam penelitian ini masih dalam kondisi baik untuk pertumbuhan bakteri Bacillus subtilis. Bakteri Bacillus subtilis merupakan bakteri jenis neutrofil akan menunjukan pertumbuhan yang tinggi pada kondisi $\mathrm{pH}$ asam [12].

Kadar oksigen terlarut selama penelitian diperoleh berkisar $2-4 \mathrm{mg} / \mathrm{L}$. Oksigen terlarut yang optimum untuk bakteri aerob dalam proses perombakan bahan organik berkisar antara $2-4 \mathrm{mg} / \mathrm{L}$ [13]. 


\section{KESIMPULAN}

Kepadatan bakteri akan mengalami peningkatan setiap 24 jam sekali seiring dengan menurunnya bahan organik pada limbah budidaya ikan Lele Sangkuriang, karena bahan organik dimanfaatkan oleh bakteri untuk pertumbuhannya.

Selama masih ada bahan organik maka bakteri akan tetap berkembang, bakteri akan menurun seiring nutrientnya habis, jika menurunkan bahan organik dalam waktu 5 hari, tetapi untuk bakteri membutuhkan waktu lebih dari 5 hari bahan organik tidak terdegradasi $100 \%$.

\section{DAFTAR PUSTAKA}

[1] Koten, E., L.L.J.J. Mondoringin dan I. R. N. Salindeho. 2015. Evaluasi Usaha Pembudidayaan Ikan di Desa Matungkas Kabupaten Minahasa Utara. Jurnal Budidaya Perairan. 3(1) : $203-210$

[2] Bureau, D.P dan K. Hua. 2010. Towards effective nutritional management of waste output in aquaculture, with particular reference to salmonid aquaculture operations. Aquaculture Research. 41 : 777-792.

[3] Arfiati, D., C.D.G. Putra., A.H.Tullah S.W.A. Permanasari dan A.W. Puspitasari. 2018. The Dynamics of Total Organik Matter (TOM) on Sangkuriang Catfish (Clarias gariepinus) Farming at UPT PTPBP2KP and the Effectiveness of Freshwater Bivalve (Anodonta woodiana) in Reduving the total Organik Matter with Varying Density. Abstrak Book The $1^{\text {st }}$ International Conference on Fisheries and Marine (InCoFIMS). Fakultas Perikanan dan Kelautan Universitas Erlangga, Surabaya Turkish Journal of Fisheries and Aquatic Sciences. 14: 615-621.

[4] Prayogo, B. S. Rahardja dan A. Manan. 2012. Eksplorasi Bakteri Indigen Pada Pembenihan Ikan Lele Dumbo (Clarias sp) Sistem Resirkulasi Tertutup. Jurnal Ilmiah Perikanan dan Kelautan. 4(2) :193-197
[5] Budianto, B dan H. Suprastyani. 2017. Aktivitas antagonis Bacillus subtilis terhadap Streptoccus iniae dan Pseudomonas flurescens. Journal Veteriner. 18: 409-415.

[6] Bakar, A.A., R. Rasol dan N. Yahya. 2015. Turbidity Method to measure the grwoth of anaerobic bacteria related to microbiologically influenced corrosion. Solid state phenomena. $227: 298-301$.

[7] Chatterjee, S.N., Syed. A.A, Mukhopandhyay, B. 2014. Density of soil bacteria in some village areas anjoining to joypur foret of Vankura distric of West Bengal, India. International Journal of Enviromental Biology. 4(1): 67-70.

[8] Setyati, W.A., E. Martani, Triyanto, Subagio, M. Zainuddin. 2014. Selection identification and optimization of Growth water probiiotic consortium of mangrove ecosysteam as bioremediation and biocontrol in shrimp ponds. JPHPI. 17(3): 243-253.

[9] Kristiawan, D., N. Widyorini dan Haeruddin.2014. Hubungan total bakteri dengan kandungan bahan organic total di Muara Kali Wiso, Jepara. Diponegoro Journal of Maquares. 3(4): 24-33.

[10] Genckal, H dan C. Tari. 2006. Alkaline protease production from alkalophilic Bacillus sp isolated from natural habitats. Enzyme and Microbial Technology. 39 : 703-710.

[11] Indriyati. 2005. Pengolahan limbah cair organik secara biologi menggunakan reaktor anaerobik lekat diam. JAI. 1(3) : 340-343.

[12] Shekhar, S.K., J. Godheja dan D.R. Modi. 2015. Hyfrocarbon bioremidiation efficiency by five infogenous bacterial strains isolated from contaminated soils. International Journal of Current Microbiology adn Applied Sciences. 4(3) : 892-905. 
[13] Yadav, T.C., A.A. Khardenavis dan A. Kapley. 2014. Shifts in microbial community in response to dissolved oxygen levels in activated sludge. Bioresource Technology. 165 : 257-264. 